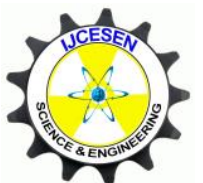

Copyright C IJCESEN
International Journal of Computational and

Experimental $\boldsymbol{S}$ cience and Engineering

(IJCESEN)

Vol. 4-No.3 (2018) 5-8

http://dergipark.gov.tr/ijcesen

Research Article

\title{
Internet Based Data Collection and Analysis of Objects in Solar Energy Production Systems
}

\author{
Serkan AYDIN ${ }^{1}$, Hakan YÜKSEL ${ }^{2}$ \\ ${ }^{1}$ Suleyman Demirel University, Technical Science Vocational School, Electricity and Energy Depart. Isparta-Turkey \\ ${ }^{2}$ Suleyman Demirel University, Technical Science Vocational School, Computer Programming Depart. Isparta-Turkey \\ * Corresponding Author : serkanaydin@sdu.edu.tr \\ ORCID: 0000-0003-1358-7579
}

\section{$\underline{\text { Article Info: }}$}

DOI: $10.22399 /$ ijcesen.358359

Received : 27 November 2017

Accepted : 30 July 2018

\section{Keywords :}

Solar Energy

Internet of Things

Renewable Energy

Microcontroller

\begin{abstract}
:
In this study, some parameters were measured during the production phase of the electricity generated by the solar panel. Light, temperature, humidity, voltage, current and power measurements were carried out during the production of the electric energy of the solar panel. Measurements were instantly transferred to the cloud technology. The Internet of Things (IoT) is very popular today. Many objects can communicate with each other. Measured data for objects can also be analyzed on an instantly, hourly, daily, etc. basis thanks to cloud technology. Renewable energy keeps updating the energy generation system of the future and it is constantly developing. In this study, the parameters measured in renewable energy systems were examined.
\end{abstract}

\section{Introduction}

It is important that the information used in automation and industrial systems be used in real time. Different systems are used to transfer this information in real time [1]. These systems generally store the measured values as a database or cloud-based. Thanks to this data, many faults are prevented. Within the system efficiency, the necessary values are obtained. These systems are often called the Internet of Things (IoT).

Internet of Things (IoT) is technologies that enable sensors to transmit data generated by sensors attached to objects wirelessly and control objects. Nowadays, it has started to have a very important place by using a lot of fields and has played an important role in the development of this technology in various fields and it continues to play important roles [2].

Usage rates of devices connected to the Internet are increasing and we use in most areas. Today, there are billions of devices connected to the Internet [3]. In recent years, the Internet of Things (IoT) has begun to be used in many areas, and some of them are smart houses. In similar systems, the measured data is stored in the cloud technology via different systems. With these records, it is possible to instantly or later display the data presented to the user's use [4]. Smart houses do not only control data and control but also they are now in the process of producing their own energy. One of the most commonly used methods of producing their own energy is solar energy.

Solar energy is an important renewable energy source. The Wi-Fi system is an important system for control systems in terms of speed and accuracy in solar panel systems. By combining similar systems, instantaneous monitoring of measured values, energy efficiency detection and prevention of failures will be facilitated [5]. Solar energy or photovoltaic systems are one of the most important sources of renewable energy resources. The charge control system in solar energy systems is the heart of the system. If charge control is well done in solar energy systems, system efficiency can reach 97 $98 \%$ [6]. There are many factors on PV panel power output in photovoltaic systems, some of which are surface temperature, panel position and electrical load resistance [7].

This study is a combination of intelligent systems such as the solar energy system, the Internet of Things, and the Arduino microcontroller system.

\section{Materials and Methods}

In this study, DHT11 air temperature and relative humidity sensor for the installed solar panel and temperature and humidity measurements of the 
environment of the solar panel were made. The LDR light sensor also was measured the light value of the solar panel. The ACS709 current sensor was measured the voltage and current values of the solar panel. With the Arduino Due microcontroller card, the values from the sensors were processed and transferred to the database using the cloud technology, with the help of the ESP8266-ESP-201 Wi-Fi module. The reason for using Arduino Due is that the values read from the sensors are processed more quickly and stably and the GPIO pins work better with the ESP8266-ESP-201 Wi-Fi module due to the operation with 3.3 volts. In the installed system, the values read from the sensors are recorded graphically in the database with the cloud technology. These values can be examined on an hourly, daily, monthly and annual basis. Figure 1 shows the block diagram of circuit components.

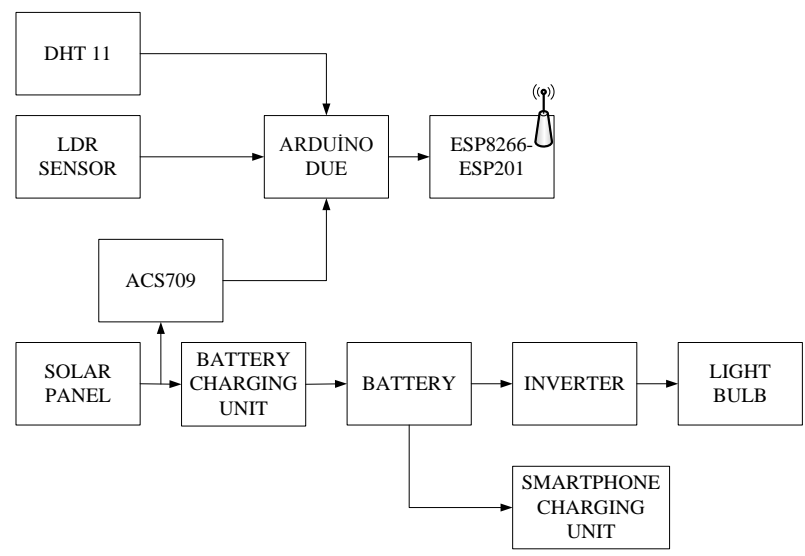

Figure 1. Circuit Components Diagram

The installed solar panel system is a 140 Watt solar panel. The electricity generated by the solar energy charges a $12 \mathrm{~V} 60 \mathrm{Ah}$ hour gel accumulator via the charging circuit with a 10 A digital sun charge regulator. The accumulator is connected to a $300 \mathrm{~W}$ inverter. $220 \mathrm{~V}$ $5 \mathrm{~W}$ three led bulbs and a socket and photocell relay control are connected to the inverter. In addition, 12V / $5 \mathrm{~V}$ six USB chargers are connected.

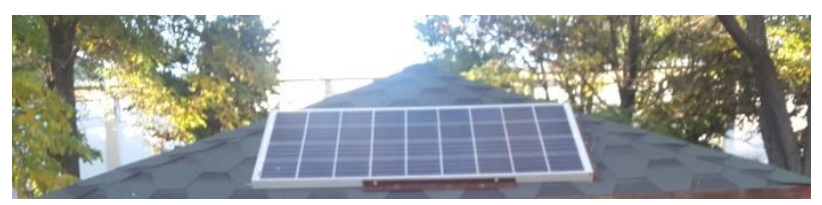

Figure 2. Installed Solar Panel System

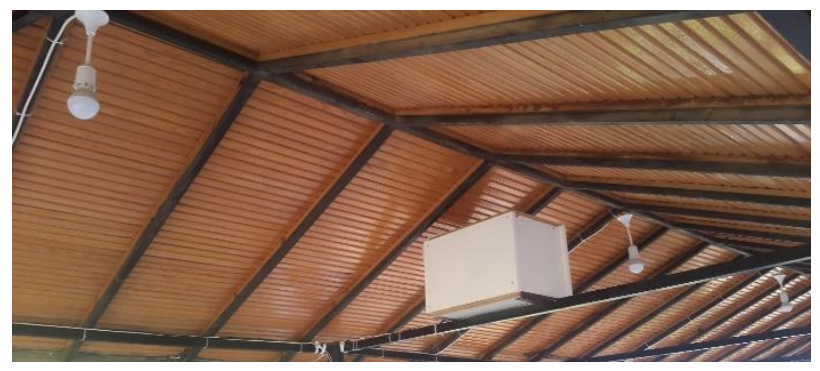

Figure 3. Charging and Wireless Data Transfer Station
For a more stable measurement, the wireless data transmission system, the algorithm is drawn in Figure 4.

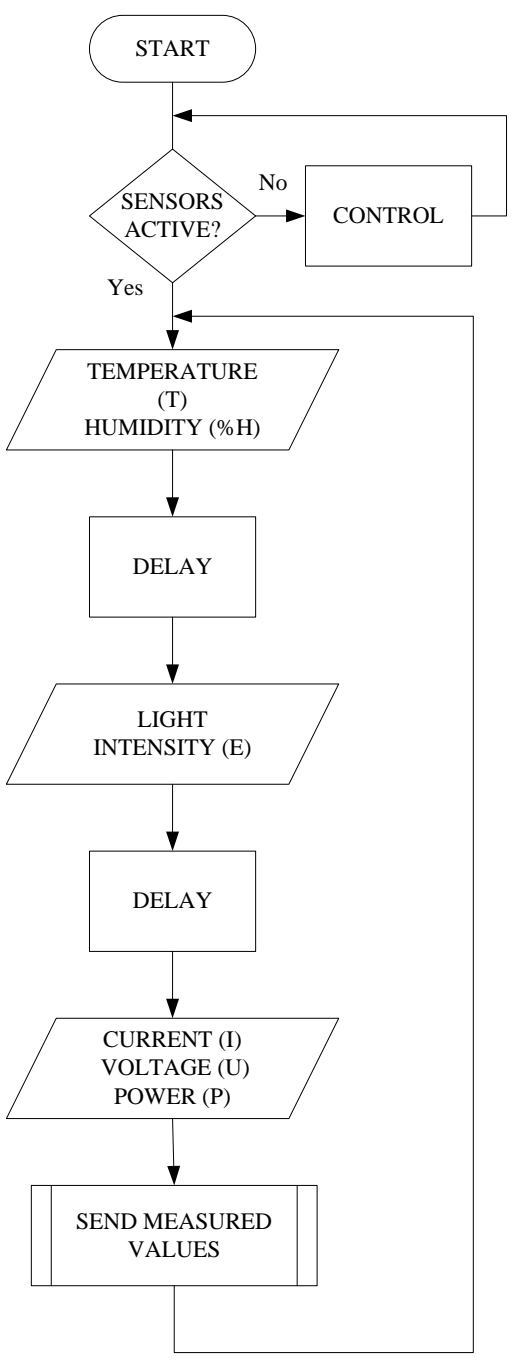

Figure 4. System Algorithm

\section{Results}

With the installation of the system, the data transferred to the cloud technology are transformed into graphics. For example, the hourly data of air temperature, relative humidity, light, current, voltage and power values are shown in Figures 5, 6, 7, 8, 9 and 10.

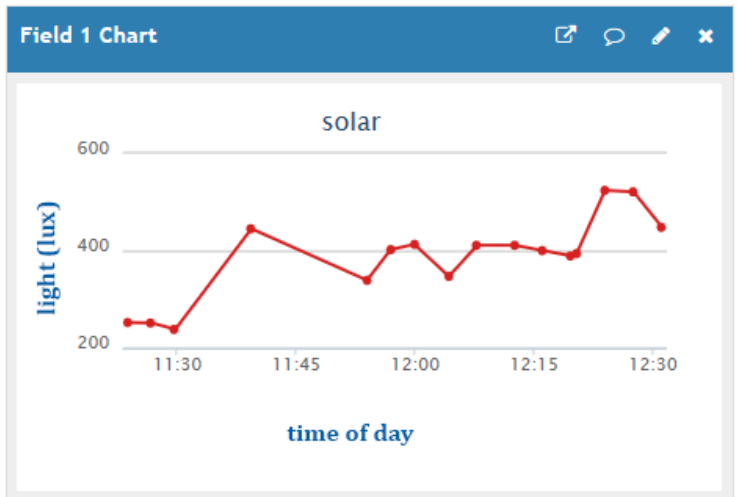

Figure 5. Data of Light 


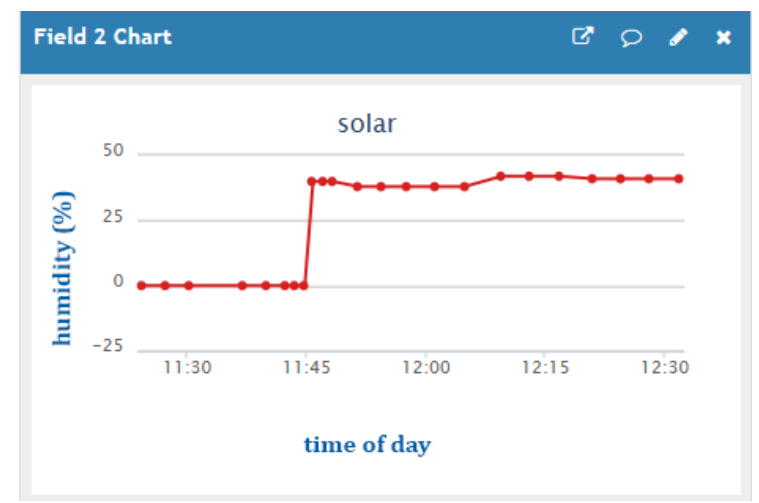

Figure 6. Data of Relative Humidity

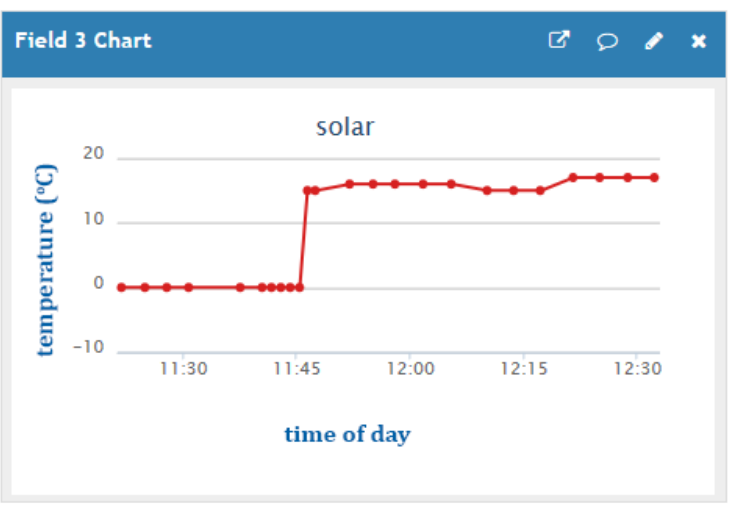

Figure 7. Data of Air Temperature

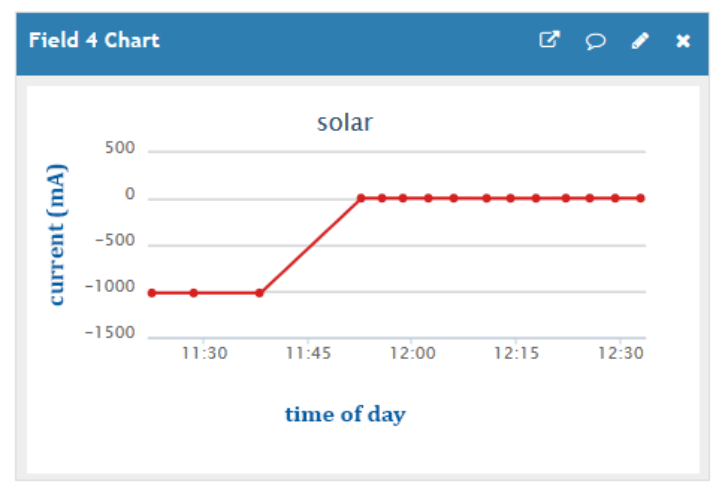

Figure 8. Data of Current

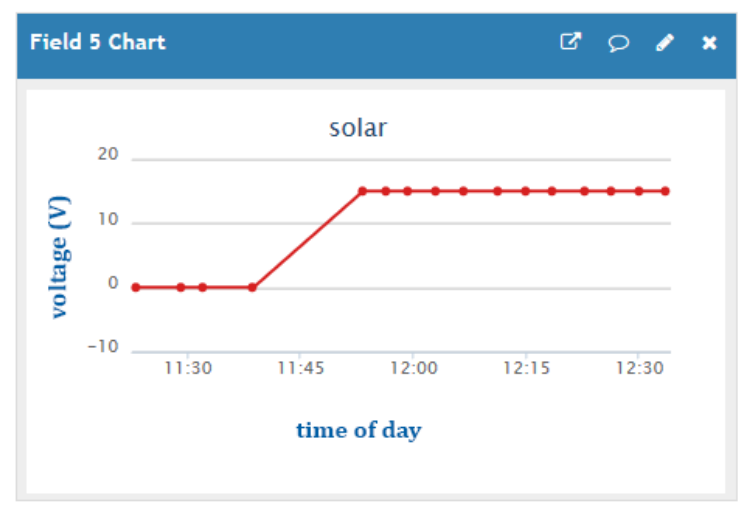

Figure 9. Data of Voltage

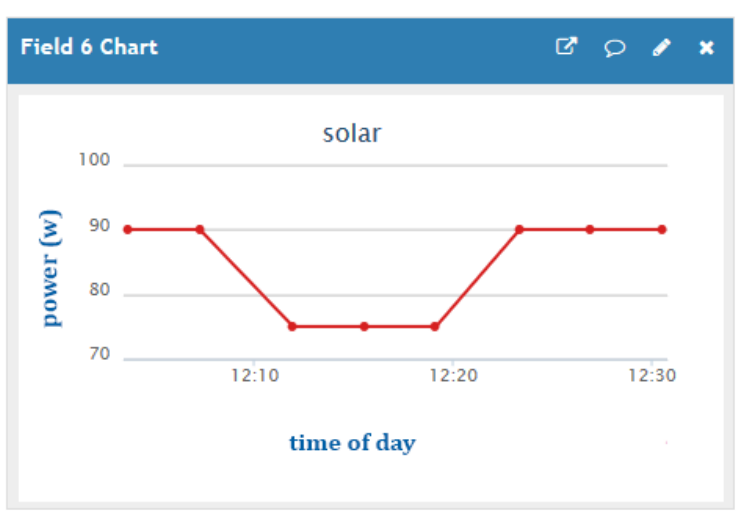

Figure 10. Data of Power

As a result of this study, the current, voltage and power values of the installed solar panel according to daylight, temperature and humidity values were recorded in the database via cloud technology. With these data, it is possible to determine at which intervals the most productive values can be reached. The measured values are recorded instantly to the cloud technology thanks to the $\mathrm{Wi}$-Fi module.

As you can see from the figures, the measurements of relative humidity, air temperature and light values as well as the voltage, current and power values produced by the solar system have been applied. In this way, the efficient working data intervals of the system will be determined and the efficiency of solar systems will be improved.

\section{Discussion}

In today's technology, developments in renewable energy and cloud technology have gained momentum. The necessary calculations can be made to remove the hot spot effect in the solar panel systems and obtain the highest efficiency. By doing these calculations, studies can be developed to determine the positioning and turning angles of solar panels.

In addition, thanks to similar work, prototypes can be installed and measurements can be made prior to solar panel installation. These measurements will ensure that more accurate information is obtained before installing more powerful solar panels.

\section{References}

[1] SSimşek, M.A., Taşdelen, K., "Denetleyici Alan Ağ Üzerinden Sensör Verilerinin İzlenmesi", SDU International Journal of Technological Science, Vol.8, No.1 (2016) pp. 20-33

[2] Köroğlu, O., "Nesnelerin İnterneti, Algılayıcı Ağları Ve Medya", Akademik Bilişim 2015 Konferansı. 
[3]Arslan, K., Kırbaş, İ., "Nesnelerin İnterneti Uygulamaları İçin Algılayıc1/Eyleyici Kablosuz Düğüm İlk örneği Geliştirme”, Mehmet Akif Ersoy Üniversitesi Fen Bilimleri Enstitüsü Dergisi Özel Say1 1 (2016) pp. 35-43

[4] Walia, N.K., Kalra, P., Mehrotra, D., An IOT by Information Retrieval approach: Smart Lights controlled using WiFi.2016 6th International Conference - Cloud System and Big Data Engineering (Confluence), IEEE. (2016) pp. 708-712

[5] Joshi, S., Jadhav, A., Gavate, N., Yashwante, M., "Wi-Fi Based Parameter Monitoring for Solar Plant", IJESC Volume 6 Issue No.4 (2016) pp. 4085-4087

[6] Rokonuzzaman M. and Haider H.E., "Design and Implementation of Maximum Power Point Tracking Solar Charge Controller", 3rd International Conference on Electrical Engineering and Information Communication Technology (ICEEICT), IEEE (2016)

[7] Işıker, Y., Yeşilata, B., Bulut, H., "Fotovoltaik Panel Gücüne Etki Eden Çalışma Parametrelerinin Araştırılması", UGHEK'2006: I. Ulusal Güneş Ve Hidrojen Enerjisi Kongresi, (2006) pp. 150-155 